\title{
PREDICATION: THE TEST For TAX AVOIDANCE IN NEW ZEALAND FROM NEWTON TO BEN NEVIS
}

\author{
John Prebble* and Hamish McIntosh ${ }^{* *}$
}

\begin{abstract}
General anti-avoidance rules in income tax legislation are a blunt instrument. They can operate most effectively when decision makers move directly from the rule, such as "Arrangements with the purpose of tax avoidance are void against the Commissioner" to the facts, for example, "Objectively, do these facts demonstrate a purpose of avoidance?", or to paraphrase Lord Denning's test, "Viewing these facts objectively, can one predicate an avoidance purpose?"
\end{abstract}

New Zealand courts adopted Lord Denning's "predication test" in 1966, but later cases confused things by trying to incorporate sub-rules into the exercise of looking for an avoidance purpose.

Parliament codified and strengthened the predication test in 1974. Inland Revenue Department archives show that strengthening and codification of the test was what was intended and the language of the amendment confirms this intention. Nevertheless, later judgments misunderstood what the predication test entailed, and mistakenly thought that Parliament intended the 1974 amendment to abolish the test and to replace it with something else.

In 2009 the Supreme Court delivered its judgment in Ben Nevis Forestry Ventures Ltd v Commissioner of Inland Revenue, the first case on tax avoidance to come before the Court. The Court said that the 1974 amendment abolished the predication test, but its reasoning in deciding the Ben Nevis case was in effect an exercise in predication.

It would be useful to employ a name for the Supreme Court's approach to tax avoidance because a name would enable people to refer to the Supreme Court's test without circumlocution.

* BA, LLB (Hons) Auckland; BCL Oxon; JSD Cornell; Inner Temple. Barrister. Professor and former Dean of Law, Victoria University of Wellington; Gastprofessor, Institut für Österreichisches und Internationales Steuerrecht, Wirtschaftsuniversität Wien; Adjunct Professor of Law, Notre Dame University, Sydney.

** BA (Hons), LLB Otago; barrister, Wellington. 
"Predication" is the appropriate name because of its accuracy as to the meaning required and because of its historical antecedents. ${ }^{1}$

\section{INTRODUCTION}

In the forestry tax shelter avoidance case of Ben Nevis Forestry Ventures Ltd $v$ Commissioner of Inland Revenue, ${ }^{2}$ the New Zealand Supreme Court explained the test for tax avoidance under s BG 1 of the Income Tax Act 1994 (now s BG 1 of the Income Tax Act 2007). McGrath J delivered the judgment of the majority, namely Tipping J, himself and Gault J. The judgment included the following:

[81] ... At the same time the [1974 amending] legislation dispensed with Lord Denning's predication test in Newton ...

[102] ... [The courts' approach to tax avoidance] must enable decisions to be made on individual cases through the application of a process of statutory construction focusing objectively on features of the arrangements involved ...

This article argues that, first, the majority in Ben Nevis erred in its understanding of the Newton predication test referred to in the passage quoted above, and also of the effect of the Land and Income Tax Amendment Act (No 2) 1974: that legislation did not dispense with the Newton predication test in New Zealand, but instead preserved it. As a result, the Newton predication test (which, in the rest of this article, the authors will often call, simply, "the predication test") remains part of the statutory interpretation exercise required in respect the New Zealand's current general anti-avoidance rule (GAAR). ${ }^{3}$ Further, in Ben Nevis, the Court unconsciously restated and applied the essence of the predication test anyway. In those circumstances, the label "predication" is not only still useful for understanding the interpretation exercise required in applying the GAAR, but also the use of the label should be resumed - not only for linguistic and jurisprudential integrity but also to assist those involved in the application of the GAAR, including taxpayers seeking to comply with that rule.

1 The authors are most grateful to the editors of the Victoria University of Wellington Law Review for this opportunity to recognise the innumerable and prolonged contributions that Professor Bill Atkin has made to the Victoria University of Wellington Law Faculty since first enrolling as a student. This special issue of the Review is a most appropriate vehicle to recognise Bill Atkin's collegial presence as a senior member of the staff of the University, and his exemplary record in teaching and research, notably his selfless work in publishing the work of others.

2 Ben Nevis Forestry Ventures Ltd v Commissioner of Inland Revenue [2008] NZSC 115, [2009] 2 NZLR 289.

3 Sections BG 1 and YA 1 of the Income Tax Act 2007. 


\section{THE MEANING OF TAX AVOIDANCE}

The concept of tax avoidance is well-known and need not be examined in depth here. For present purposes, we mean, broadly, the form of tax minimisation that involves the creation or deployment of commercial arrangements that specifically seek to use (or misuse, or abuse) the law to minimise tax that would otherwise be payable. ${ }^{4}$ In the words of James Kessler, tax avoidance constitutes: ${ }^{5}$

... contriving transactions typically but not necessarily artificial in nature, to reduce tax that would

otherwise be payable according to what appears to be the policy of the taxing provision in question.

More specifically, this article uses the term "tax avoidance" to refer to the legal status or consequence of an arrangement that falls within the ambit of GAARs in general and of the New Zealand GAAR in particular.

An early New Zealand example of tax avoidance was the arrangement in Mangin $v$ Commissioner of Inland Revenue. ${ }^{6}$ The taxpayer, Mr Mangin, was a farmer. In 1965, he leased a 25acre paddock of his farm to trustees for a year, at a rental of $£ 3$ per acre. Mr Mangin sowed the land in wheat, and harvested the wheat, as an employee of the trustees, who paid for his labour and certain expenses. Under a separate trust deed, the resulting income was to be held on trust for his wife and children. In 1966, the process was repeated, with a different 24 acres. In each year, Mr Mangin received the proceeds of the wheat and handed them over to the trustees, who distributed the bulk of the net income that they received for the benefit of Mr Mangin's wife and children. $\mathrm{Mr}$ Mangin did not include the monies paid to the trustees in his tax returns, but the trustees did return the income. As agents, the trustees paid tax for the beneficiaries at their personal rates. The Commissioner decided that the arrangements constituted tax avoidance. The Court of Appeal upheld the Commissioner's reassessment, and ultimately so did the Privy Council, holding that the scheme

4 Tax avoidance can be contrasted with two other categories of tax minimising conduct, namely: (i) tax mitigation, which refers to minimisation through entirely lawful means, such as buying tax-preferred investments, or giving income-producing property to one's children; and (ii) tax evasion, being the criminally sanctioned conduct of minimising tax by unlawful means, such as failing to declare income or altering records. Although the categorisation identified here is widely accepted, many people prefer not to

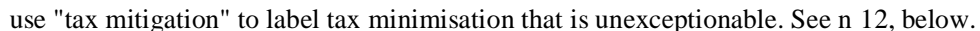

5 James Kessler "Tax Avoidance Purpose and Section 741 of the Taxes Act 1988" (2004) 4 BTR 375 at 376 Compare Ben Nevis Forestry Ventures Ltd v Commissioner of Inland Revenue, above n 2, at [107] per McGrath $\mathbf{J}$ for the majority: "If ... it is apparent that the taxpayer has used [a] specific provision [of the Income Tax Act], and thereby altered the incidence of income tax, in a way which cannot have been within the contemplation and purpose of Parliament when it enacted the provision, the arrangement will be a tax avoidance arrangement."

6 Mangin v Commissioner of Inland Revenue [1971] NZLR 591 (PC). 
was devised for the sole purpose, or at least the principal purpose, of enabling Mr Mangin to escape tax liability for a substantial part of the income that he would otherwise have derived. ${ }^{7}$

Cridland v Federal Commissioner of Taxation is an Australian example from the same period that aptly demonstrates the contradictions and difficulties inherent in the concept of tax avoidance. ${ }^{8}$ Section 157 of the Income Tax Assessment Act 1936 (Cth) entitled primary producers to spread their income over several years, thereby smoothing the tax rate payable. The taxpayer, Mr Cridland, became a AUD 1 unit holder in a unit trust that farmed cattle when he was an engineering student. Upon graduating and becoming employed, but being still a unit holder, Mr Cridland sought to take advantage of s 157 to average his income over previous years, including the years when he was a student. The Commissioner refused to allow the averaging claimed, viewing the unit holding to be in the circumstances only an arrangement to avoid tax. The Supreme Court of New South Wales agreed with the Commissioner, but on appeal the High Court of Australia ruled that Mr Cridland was entitled to the statutory benefits of the steps that he had taken, despite his having taken those steps purely for the purposes of minimising tax. ${ }^{9}$

\section{THE STATUTORY INTERPRETATION CHALLENGE}

In order that GAARs will apply to the widest possible range of arrangements (including those yet to be conceived), typically the rules are expressed: (i) in general terms only; and (ii) to focus on the purpose or effect of arrangements. ${ }^{10}$ Those characteristics can, however, create a challenge for courts in interpreting and applying GAARs. The reason is that in order to ascertain purposes from facts, a court cannot, without using additional rules or glosses, rely solely on the words of GAARs themselves, but instead must derive its own conclusions directly from that facts of the case in question, as will become apparent in this article.

Nor can courts necessarily rely on tests and/or rules set down in earlier judgments that apply GAARs, because inconsistent usage of terms between judgments invites resort to purely linguistic arguments, that is, arguments that depend on how an earlier court has used a crucial word rather

7 At 598 (Lord Wilberforce dissenting).

8 Cridland v Federal Commissioner of Taxation (1977) 140 CLR 330 (HCA).

9 In light of the decision in Mangin v Commissioner of Inland Revenue, it is likely that New Zealand courts would have reached the opposite conclusion on the question.

10 For example, from s YA 1 of the Income Tax Act 2007:

tax avoidance arrangement means an arrangement, whether entered into by the person affected by the arrangement or by another person, that directly or indirectly-

(a) has tax avoidance as its purpose or effect; or

(b) has tax avoidance as 1 of its purposes or effects, whether or not any other purpose or effect is referable to ordinary business or family dealings, if the tax avoidance purpose or effect is not merely incidental 
than on a substantive meaning always inherent in the word in question. ${ }^{11}$ Moreover, in the early days of New Zealand's GAARs, the absence of any positive determinations of tax avoidance, or of settled tests being used in such decisions as there were, made the task even more difficult.

In those circumstances, the statutory interpretation exercise involved in applying a typical GAAR requires the use of a process whereby one can progress directly from the facts to the legal result, in a way that fairly and consistently differentiates arrangements that minimise tax that are legitimate from arrangements that fall to the GAAR.

\section{THE INTRODUCTION OF THE NEWTON PREDICATION TEST}

In the Privy Council's decision in Newton v Commissioner of Taxation of the Commonwealth of Australia, ${ }^{12}$ Lord Denning explained how tax avoidance could be identified under the then Australian GAAR, ${ }^{13}$ which provided as follows:

Every contract, agreement, or arrangement made or entered into, orally or in writing, whether before or after the commencement of this Act, shall so far as it has or purports to have the purpose or effect of in any way, directly or indirectly -

(a) altering the incidence of any income tax;

(b) relieving any person from liability to pay any income tax or make any return;

(c) defeating, evading, or avoiding any duty or liability imposed on any person by this Act; or

(d) preventing the operation of this Act in any respect,

be absolutely void, as against the Commissioner, or in regard to any proceeding under this Act, but without prejudice to such validity as it may have in any other respect or for any other purpose.

In delivering the judgment of their Lordships, Lord Denning said: ${ }^{14}$

In order to bring the arrangement within the section you must be able to predicate - by looking at the overt acts by which it was implemented - that it was implemented in that particular way so as to avoid tax. If you cannot so predicate, but have to acknowledge that the transactions are capable of explanation by reference to ordinary business or family dealing, without necessarily being labelled as a means to avoid tax, then the arrangement does not come within the section.

11 For example, Lord Templeman's separate concepts of "tax avoidance" and "tax mitigation" as expressed in Challenge Corporation Ltd v Commissioner of Inland Revenue [1986] 2 NZLR 513 (PC) at 548 were rejected in (among others) Miller v Commissioner of Inland Revenue [2001] 3 NZLR 316 (PC) at 326 and Ben Nevis Forestry Ventures Ltd v Commissioner of Inland Revenue, above n 2, at [95], despite those subsequent courts arguably taking his words materially out of context. (And as we shall also see, Lord Denning's term "predication" was soon misunderstood and misapplied.)

12 Newton v Commissioner of Taxation of the Commonwealth of Australia [1958] AC 450 (PC).

13 Section 260 of the Income Tax and Social Services Contribution Assessment Act 1936-1950 (Cth).

14 Newton v Commissioner of Taxation of the Commonwealth of Australia, above n 12, at 465-466. 
Applying these principles to the present case, the first question is - Was there an arrangement? The answer is "Yes". The whole complicated series of transactions must have been the result of a concerted plan; and the nature of the plan is to be ascertained by the overt acts done in pursuance of it.

The first two sentences in this passage soon became known and adopted in the Commonwealth as the Newton predication test. ${ }^{15}$

As can be seen from the language that Lord Denning used, the test: (i) appeared to be comparatively short and straightforward; (ii) described a process for progressing from the facts directly to the legal conclusion; and (iii) was intended to have general application. Nevertheless, because the test was founded on the concept of "predication" as used in logic, and also, as we will see, because misconceptions about that term soon arose, before examining the historical progress of the test we need first to understand its fundamental elements.

\section{ANALYSIS OF THE PREDICATION TEST}

First, the relevant meaning of the verb "to predicate" is to assert, in the context of logical reasoning, something about the subject of a proposition. ${ }^{16}$ Consequently, where the relevant "subject" is a given set of facts, the process of predication about those facts is in essence the process of reasoning by deduction to work out what the facts mean or result in, in relation to the relevant proposition made about them. (In the present context, the relevant proposition is that the facts together amount to an arrangement that has a purpose of tax avoidance, more frequently put in the form of a question such as, "Do the facts amount to an arrangement for tax avoidance?"). Thus, among other things, the predication test helpfully identified and stated its own internal analytical process. Furthermore, and again as matter of logic, no matter how that process may be otherwise labelled or described, predication is in principle the only possible way to move directly from a set of facts to their legal result without using any intermediate or additional rules or glosses.

Next, the test was expressed as having two distinct parts or steps, being its two sentences. Thus (at least with reference to the Australian s 260):

- if it was possible to predicate initially that the arrangement was implemented as it was in order to avoid tax, then one would conclude that the arrangement constituted tax avoidance (that is, the first sentence); but

15 The test was adopted for the interpretation of New Zealand's GAAR in Elmiger v Commissioner of Inland Revenue [1966] NZLR 683 (SC) at 691 per Woodhouse J, and affirmed on appeal.

16 Oxford English Dictionary, definition of the verb "to predicate" at 2(a) (logic): Oxford English Dictionary <www.oed.com>. Since Lord Denning was a mathematician by training, it is a reasonable assumption that he intended the term to have that meaning in the context that he was using it. 
- if it was not possible to so predicate, then the arrangement needed to be further analysed, with the result that the arrangement might or might not constitute tax avoidance (that is, the second sentence).

Further, the test clearly identified the mechanics of implementation of the subject arrangements as the proper basis for the predication of their purpose or effect, rather than the motives of the individuals concerned. ${ }^{17}$

Lastly, as a result of the above elements, the test could in principle be applied: (i) by anyone, be they taxpayer, tax collector or arbiter; and (ii) to any given arrangement.

It should not be thought from the above isolation of the elements of the test that Lord Denning's formulation was flawless. Indeed, on a rigorous logical analysis the test can be faulted, or at least shown to be incomplete. For example, the words of the second sentence do not tell us expressly that a further process of analysis may be required, or what is supposed to happen if either:

- $\quad$ the arrangement is not explicable by reference to an ordinary business or family dealing at all; or, instead

- it is so explicable, but it also appears to have the purpose of avoiding tax.

In the first of those possibilities, it is not entirely clear from the words of the second sentence how the test responds, considering that initial predication in respect of the arrangement was not possible. Could such arrangement (for example, a completely novel one) still be diagnosed as having the purpose of tax avoidance? Yes - Lord Denning certainly intended such a possibility, which was why he expressed the second sentence as he did, rather than simply leaving the first sentence to stand alone, or merely proceeding to state its inverse in the second sentence. If so, however, how is that tax avoidance purpose or effect to be determined; that is, how is the second step supposed to work?

The answer is that by his use of the qualification - "without necessarily being labelled as a means to avoid tax" - Lord Denning intended that in such cases a second and closer look needed to be taken at all the facts and circumstances, as a result of which exercise a positive conclusion of tax avoidance might still be reached. For example, under closer scrutiny a single and seemingly less

17 Newton $v$ Commissioner of Taxation of the Commonwealth of Australia, above n 12, at 465 per Lord Denning (footnote omitted): "... the section is not concerned with the motives of individuals. It is not concerned with their desire to avoid tax, but only with the means which they employ to do it. It affects every 'contract, agreement or arrangement' (which their Lordships will henceforward refer to compendiously as 'arrangement') which has the purpose or effect of avoiding tax. In applying the section you must, by the very words of it, look at the arrangement itself and see which is its effect - which it does - irrespective of the motives of the persons who made it. Williams $\mathbf{J}$ put it well when he said: 'The purpose of a contract, agreement or arrangement must be what it is intended to effect and that intention must be ascertained from its terms. Those terms may be oral or written or may have to be inferred from the circumstances but, when they have been ascertained, their purpose must be what they effect'." 
significant step in an arrangement might prove in context to be sufficiently unusual or inexplicable that one might still reach a conclusion about the real purpose of the arrangement overall. Selfevidently, however, even such a secondary process of reasoning still requires predication for its conclusion. In other words, you are still predicating from the facts that the arrangement has a purpose of tax avoidance. If so, however, logically, how could you predicate tax avoidance in the second step when you only ever got to that step because (under the first step) you could not predicate tax avoidance?

Moreover, in respect of the other possible outcome of the second step noted above (that is, an ordinary business or family dealing that does have a purpose of tax avoidance), the sense of the words used by Lord Denning makes it clear that such an arrangement was intended to be caught by the provision. If so, however, how do you come to that conclusion other than by predicating it from the facts, and if you have predicated it in that manner, why, then, could you not have done so at the first step; that is, at the outset?

It must be remembered that Lord Denning was explaining how the statutory provision was to be applied; he was not attempting to redraft it. It is therefore neither fair nor appropriate to interpret his words with the same rigour that one would employ in interpreting a statute. He was also not advocating an arid exercise in logic to be applied rigidly in every case. Rather, he was in the first instance describing a judicial process in respect of a specialised area of law that necessarily involves judicial skills, experience and knowledge of previous cases. Considering the words that his Lordship used and their context, there is little doubt that he was intending a two-step analysis when two steps are needed. That is, his Lordship envisaged that where examining an impugned arrangement on its face fails to yield a positive result, a second, closer, analysis may be necessary: in effect, two levels of review. Further, the fact that ultimately both reviews will use the same logical reasoning process (that is, predication), does not invalidate or diminish the test.

Thus the predication test did not simply require an exercise in predication where, even if predication showed that there was a tax avoidance purpose, there might be exceptions in respect of ordinary family or business transactions. On the contrary, and at the cost of employing a triple negative, the test stipulated that even if an objective overview of the arrangement did not lead the observer to predicate a tax avoidance purpose, that result did not necessarily mean that the arrangement in question did not have a purpose of tax avoidance. More refined analysis might reveal a tax avoidance purpose. To put the proposition in other words, study of an arrangement might show it to seem unexceptionable because it appears to be an ordinary business or family dealing; but such a result is not unqualified. The second step in Lord Denning's test allowed for the possibility that even such dealings, or such dealings in combination with other factors, could amount to tax avoidance.

Before leaving Newton, note first that the term "predication" in itself explains nothing about any given arrangement: in context, "predication" is no more than the name of the reasoning process (albeit an apt name) by which statutory provisions (here, GAARs) are applied to a given sets of 
facts. It is the result of the predication exercise that has explanatory force. Secondly, it may be thought that giving that reasoning process an abstract label like "predication" serves little useful purpose. But identifying one's thinking or reasoning processes by name is a useful technique of metacognition. Generally, naming a reasoning process: (i) helps us to identify the process and to check whether it is appropriate to the task at hand; and (ii) avoids the need to resort to circumlocution when one refers to the process. In the context of interpreting a GAAR there are additional benefits. First, understanding and using the expression "predication test" can be a reminder that the object of the test is to respond to the statutory interpretation challenge identified in Part I of this article. Secondly, the term "predication" can help users focus on the true essence and ambit of the test as intended by Lord Denning, both in applying the test and in identifying how tests employed by later courts have departed from his Lordship's benchmark (although, as Parts X and XI of this article explain, in 2009 the Supreme Court appeared unconsciously to return to the predication test in Ben Nevis. $)^{18}$

\section{ELMIGER: ADOPTION OF THE NEWTON PREDICATION TEST IN NEW ZEALAND}

In Elmiger $v$ Commissioner of Inland Revenue, the taxpayers, two brothers in partnership as agricultural contractors, transferred two heavy earthmoving machines to themselves as trustees of a newly formed family trust. ${ }^{19}$ They then hired the machinery back from the trust. The particular financial terms of the arrangement enabled the brothers to retain in their own hands the bulk of the hire charges paid to the trust while still claiming the charges as deductible expenses of the partnership.

In the High Court, Woodhouse J had to determine whether the arrangement was caught by s 108 of the Land and Income Tax Act 1954, which provided (similarly to the Australian s 260, the statutory provision at issue in Newton) as follows:

Every contract, agreement, or arrangement made or entered into, whether before or after the commencement of this Act, shall be absolutely void in so far as, directly or indirectly, it has or purports to have the purpose or effect of in any way altering the incidence of income tax, or relieving any person from his liability to pay income tax.

In his judgment, his Honour discussed Australian authorities leading up to Newton and the lower court judgments in Newton itself, before referring at length to Lord Denning's statements, in particular to the predication test. He concluded: ${ }^{20}$

18 Ben Nevis Forestry Ventures Ltd v Commissioner of Inland Revenue, above $\mathrm{n} 2$.

19 Elmiger v Commissioner of Inland Revenue, above n 15, at 691 per Woodhouse J, as affirmed on appeal.

20 At 694 
On the principles laid down by the Privy Council, therefore, and taking into account the Australian decisions, it seems that the application of s. 108 will depend first upon a decision as to whether an income tax advantage was one of the actuating purposes of the transaction under review; or whether it is "capable of explanation by reference to ordinary business or family dealing, without necessarily being labelled as a means" for obtaining such a tax advantage. (See Newton's case [1958] A.C. 450, 466). And this decision is to be made objectively by looking at the overt acts done in pursuance of the whole arrangement (ibid., 465). ... Accordingly it is my opinion that family or business dealings will be caught by s. 108 despite their characterisation as such, if there is associated with them the additional purpose or effect of tax relief (in the sense contemplated by the section) pursued as a goal in itself and not arising as a natural incident of some other purpose. If this were not so I suppose an appropriate legal window dressing could still be devised to defeat the general objects of the section.

Three observations can be made about this passage. First, there can be no doubt that Woodhouse $\mathrm{J}$, whose judgment was affirmed unanimously on appeal: ${ }^{21}$ (i) understood and agreed with the fundamental features of the predication test, as discussed earlier in this article; and (ii) applied that test in the case before him. Indeed, Wild CJ later confirmed as much in Marx v Commissioner of Inland Revenue: ${ }^{22}$

In my opinion the first question is to be approached on the lines laid down by the Judicial Committee in Newton v. Commissioner of Taxation [1958] A.C. 450; [1958] 2 All ER 759. That case was decided on s. 260 of the Australian Income Tax and Social Services Contribution Assessment Act 1936-1951 which is the counterpart of, though different in terms from, s. 108 of the New Zealand Land and Income Tax Act 1954. In Elmiger v Commissioner of Inland Revenue [1966] N.Z.L.R. 683, 693, Woodhouse J. said that the difference in language did not "have any great practical significance when one is considering the scope of the two sections in so far as arrangements directed to obtaining an income tax advantage are concerned". It seems to me that in the Court of Appeal ([1967] N.Z.L.R. 161), where Woodhouse J.'s decision was affirmed, North P. was of the same opinion and, even though Turner and McCarthy JJ. expressed reservations about the applicability of cases decided on the Australian Act, it is clear that all three Judges did apply the essential test stated in Newton's case (supra). With adaptations, then, to fit the language of the New Zealand provision I extract the following principles from the judgments in Newton's case:

$\ldots$

4. The purpose and effect [of an impugned arrangement] is ascertained by examining the overt acts by which the arrangement was implemented. If on that examination it can be predicated that it was so implemented as to alter the incidence of or bring about relief from tax then it is within the section (ibid., 466,764 ) even if there were other purposes as well. It is enough if that was one of the purposes (ibid., $467,764)$.

21 Elmiger v Commissioner of Inland Revenue [1967] NZLR 161 (CA).

22 Marx v Commissioner of Inland Revenue [1969] NZLR 464 (SC) at 467-468. 
5. If it cannot be predicated that the arrangement was implemented in that way so as to alter the incidence of or bring about relief from tax, but it is capable of explanation by reference to ordinary business or family dealing without necessarily being labelled as a means of altering the incidence of or relief from tax, then it is not caught by the section (ibid., 466, 764).

A few years later, in Commissioner of Inland Revenue v Gerard, McCarthy P said: "Newton's case ... is the foundation of all our case law in New Zealand in relation to [the GAAR]."23

For practical purposes, therefore, in New Zealand the Newton predication test could be called the "Newton and Elmiger predication test".

Although it is not widely appreciated, as Part IX of this article explains, New Zealand's current GAAR (that is, the combination of ss BG 1 and YA 1 in the Income Tax Act 2007) ${ }^{24}$ is based on Woodhouse J's words in Elmiger. That is, because, as this Part of the article explains, Elmiger expressly adopted and applied the Newton predication test, it follows that the current GAAR is also based on that test.

Thirdly, however, notwithstanding the clarity of the position as set down in Elmiger, two related trends away from that clear position soon appeared.

\section{MISREPRESENTATIONS OF THE NEWTON PREDICATION TEST}

The first trend was a combination of interpretation errors made in respect of the predication test, leading over time to a complete misunderstanding, diminution and ultimate discarding (or so it was thought) of that test.

The first such error was the deliberate or unconscious reading down of, or failure to give due weight to, the qualification in the second step of: "without necessarily being labelled as a means to avoid tax". That error was possibly assisted inadvertently, first, by their Lordships in Mangin, in affirming the Court of Appeal's decision, by their alternative expression of the qualification in terms of "purpose": 25

In their Lordships' view this passage [that is, the predication test], properly interpreted, does not mean that every transaction having as one of its ingredients some tax saving feature thereby becomes caught by a section such as s 108. ... The clue to Lord Denning's meaning lies in the words "without necessarily being labelled as a means to avoid tax". Neither of the examples above given could justly be so labelled. Their Lordships think that what this phrase refers to is, to adopt the language of Turner $J$ in the present case "a scheme ... devised for the sole purpose, or at least the principal purpose, of bringing it about

23 Commissioner of Inland Revenue v Gerard [1974] 2 NZLR 279 (CA) at 283.

24 See Part X below.

25 Mangin v Commissioner of Inland Revenue, above n 6, at 598. 
that this taxpayer should escape liability on tax for a substantial part of the income which, without it, he would have derived."

In this passage, their Lordships appeared to think that with his words, "sole purpose or at least the principal purpose", 26 Turner J purported to express the test to be employed in applying s 108 of the 1954 Act. That is, that s 108 did not merely require, as its language stipulated, "the purpose or effect of ... relieving any person from his liability to income tax". Rather, the section demanded that the purpose or effect in question had to be the "the sole purpose, or at least the principal purpose" of the arrangement at issue.

Neither s 108 (nor, for that matter, its predecessors or successors) contained any mandate for adding this additional language; Turner $\mathbf{J}$ did not mean to add it, and an objective reading of his judgment shows that he did not do so. On the contrary, as his Honour explained, he meant, of $\mathrm{Mr}$ Mangin's arrangement, that "the whole scheme smacks of such business unreality" that "the only possible inference to be drawn from the facts of the arrangement"27 was not just that the purpose or effect of the scheme was to relieve Mr Mangin from income tax, but that this purpose was the scheme's sole or principal purpose. That is, the scheme easily cleared the bar of having "the purpose or effect of ... relieving [Mr Mangin] from his liability to income tax". Seen in their correct light, Turner J's words were an a fortiori conclusion, but their Lordships construed and applied them as embodying the test itself and in so doing raised the bar higher than Parliament's words imported.

The case of Udy v Commissioner of Inland Revenue ${ }^{28}$ soon followed, before Wild CJ, who probably did not appreciate that their Lordships had misinterpreted Turner $\mathbf{J}$, though it is fair to say that even if he had done so he would no doubt have been bound by their Lordships' misinterpretation. Wild CJ considered their Lordships' words in Mangin that are quoted above, and in his judgment in $U d y$ he revised his earlier statements in Marx, ${ }^{29}$ saying $:{ }^{30}$

In an earlier judgment, Marx v CIR [1969] NZLR 464, 468, I set out for my own guidance the principles which, on the language of s 108 and the case law as it then stood, I considered should govern the question whether or not s 108 applies to a given situation. I made the same approach in Wisheart v CIR (1969) 1 ATR 434, 441, and I will do the same again in this case. In the light, however, of the recent opinion of the Judicial Committee in Mangin v CIR [1971] NZLR 591; [1971] AC 739, adopting the language of Turner $\mathbf{J}$ in the Court of Appeal in that case, [1970] NZLR 222, 236, I think that my propositions numbered 4 and 5 require to be restated and put together as follows:

26 Commissioner of Inland Revenue v Mangin [1970] NZLR 222 (CA) at 236.

27 At 236.

28 Udy v Commissioner of Inland Revenue [1972] NZLR 714 (SC).

29 See Part VI and n 22, above.

30 Udy v Commissioner of Inland Revenue, above n 28, at 717. 
" 4 The purpose and effect is ascertained by examining the overt acts by which the arrangement was implemented. If on that examination it can be predicated that the scheme was devised for the sole purpose, or at least the principal purpose, of bringing it about that the objector should escape liability on tax for a substantial part of the income which, without it, he would have derived, then it is within the section. If it can not be so predicated then the scheme is not caught."

As can be seen from Wild CJ's reformulation of the test, the original wording of the qualification was removed entirely, in favour of the alternative expression of "principal purpose". Equally significantly for present purposes, the whole test was thus reformulated on a binary outcome basis. While ultimately that outcome was still consistent with the operation of the test (because, as discussed in Part V above, the exercise of predication was still the essence of both steps), it seems to have fuelled a misinterpretation that the second step had no operative substance in itself, and was semantically only the inverse of the first step. Moreover, that reformulation was then adopted in a close succession of judicial decisions applying s 108, leading to a series of defeats for the Commissioner of Inland Revenue. ${ }^{31}$

Departmental records discussed in Part IX of this article show that the Commissioner himself was under no such misapprehension about the predication test, nor did he have any intention of that test being dispensed with in the then forthcoming amendment to s $108 .^{32}$ The Commissioner's view, as expressed in a letter dated 25 September 1974 to the Minister of Finance (discussing third party commentary on the proposed amendment to s 108), ${ }^{33}$ was that the correct explanation of Lord Denning's qualification had been given by Gibbs $\mathbf{J}$ in the High Court of Australia in Hollyock $v$ Federal Commissioner of Taxation, when he said: ${ }^{34}$

To say that the section applies only to arrangements whose sole purpose is tax avoidance would be contrary to the decisions in Newton's case and Hancock's case. To hold that tax avoidance should be the principal purpose of the arrangement ... would introduce into s. 260 a refinement which is not suggested by the words of the section itself, and which would tend to increase, rather than remove, the difficulties to which this section gives rise, by requiring the courts to weigh one purpose against another and to decide which was predominant. An arrangement ... does not in my opinion escape from s. 260 simply because it cannot be held that the avoidance of tax is the principal purpose of the scheme. On the other hand, if tax avoidance is an inessential or incidental feature of the arrangement, that may well serve to show that the arrangement cannot necessarily be labelled as a means to avoid tax.

31 McKay v Commissioner of Inland Revenue [1972] NZLR 723 (SC); Martin v Commissioner of Inland Revenue [1973] 2 NZLR 733 (CA); O'Kane Construction Co. Ltd v Commissioner of Inland Revenue [1974] 1 NZLR 707 (SC); and Commissioner of Inland Revenue v Ashton [1974] 2 NZLR 321 (CA).

32 Inland Revenue Department files (including correspondence; official and briefing papers; and general travaux) on the proposed amendment to s 108 in 1974 (Obtained under Official Information Act 1982 Request to the Inland Revenue Department).

33 See n 32, above.

34 Hollyock v Federal Commissioner of Taxation (1971) 125 CLR 647 (HCA) at 657. 
(Several observations can be interposed here about the Hollyock decision. First, it continued a pattern of Australian cases that had not followed New Zealand's divergent "principal purpose" path, preferring to remain more faithful to the original qualification in the predication test. Secondly, while, just as their Lordships had done in Mangin, Gibbs J gave the Newton qualification a different expression, his alternative expression was more in keeping with the purpose of the qualification, and hence with the overall test, as intended by Lord Denning. Thirdly, as we will later see, it was the Hollyock clarification of the Newton qualification that policy makers wished to see incorporated in the 1974 amendment to s 108, and which Parliament did incorporate, not the "principal purpose" approach of their Lordships in Mangin.)

In any event, whatever its cause, the alteration of the qualification possibly facilitated a more general misinterpretation of the predication test, namely that the second sentence became taken to mean that if the arrangement was explicable by reference to an ordinary business or family dealing, then either: (i) predication was thus simply not possible (that is, "... you cannot predicate ..."), or it was unnecessary; or (ii) such arrangements could be taken as legitimate "exceptions" to that exercise, in either case thus passing the predication test. In other words, if there really was a second step in the test at all, then it did not apply to such arrangements.

That misinterpretation thus ignored not only the qualification but also Lord Denning's adjuration in the first sentence (as confirmed by the opening words of the second sentence) that predication should be attempted first. The misinterpretation thus had the effect of, among other things, completely reversing the analytical process that Lord Denning had envisaged. Nevertheless, as a result of the substituted "principal purpose" test, of the misinterpretations that have been discussed, and of the series of defeats suffered by the Commissioner, ${ }^{35}$ a further misconception arose about $\mathrm{s}$ 108 that if an arrangement could be characterised as being an ordinary business or family dealing, then it could not be stigmatised as having a tax avoidance purpose for purposes of s 108, or at least was not intended to be proscribed as having such a purpose. The situation caused the Commissioner, in a letter to the Minister of Finance dated 25 September 1974, to comment: ${ }^{36}$

Since the Elmiger decision, dicta from New Zealand cases (and not an Australian case as you may have been [led] to believe) and from the Privy Council in relation to a New Zealand case [have] tended to erode the position of the Revenue as stated in Elmiger. For instance:

- It has been suggested that tax avoidance had to be the "sole or principal purpose".

- Also that the taxpayer needed to be a direct party to the arrangement.

- Undue weight was being given to "ordinary business or family dealing" as justifying the arrangement compared with the dicta ... of Justice Woodhouse [in Elmiger].

35 See n 31, above; and Grierson v Commissioner of Inland Revenue (1971) 3 ATR 3 (SC).

36 See n 32 and 33 , above. 
As time went by, the misunderstanding of Lord Denning's second sentence deepened. The misunderstanding eventually led to the test becoming defined by its exceptions alone, with the result that the "predication test" came to be understood as being simply and only a test whereby an arrangement would not constitute tax avoidance if it could be explained by reference to ordinary business or family dealings. That is: (i) the test no longer focused on an objective assessment of an impugned arrangement that might inculpate the arrangement. Instead, what Lord Denning had postulated as possible exceptions (business or family dealings) had become the test itself, operating to exculpate, or to save, the arrangement; and (ii) predication as a process was no longer the essence of the test, but simply its name. For example, in Challenge Corporation Ltd v Commissioner of Inland Revenue, after describing the numerous challenges to s 108 that occurred from the mid-1960s and ultimately led to the 1974 amending legislation, Richardson $\mathbf{J}$ said: $:^{37}$

Thus [under section 108 of the 1974 Act an arrangement] is not saved by the old predication test of ordinary business dealing if any purpose other than a merely incidental purpose is tax avoidance.

A similar mischaracterisation of the test occurred in Ben Nevis. The Ben Nevis Court did not cite Richardson $\mathrm{J}$ on this point, but the reader's impression is that their Honours, knowing of Richardson J's vast knowledge not only of tax law but also of the policy and legislative history of amendments to income tax legislation, assumed that if Richardson $\mathbf{J}$ said that Parliament had dispensed with something, dispensed with it must have been, and there was no need to check legislative history. The majority said: ${ }^{38}$

At the same time the [1974 amending] legislation dispensed with Lord Denning's predication test in Newton by stating that an arrangement could amount to tax avoidance whether or not other purposes or effects of the arrangement were referable to ordinary business or family dealings.

It is possible that these judicial statements were intended to refer only to the predication test, and not to the concept of predication itself. However, the words used indicate an understanding that the concept of predication belonged particularly to the Newton and Elmiger predication test, and/or was in context a concept inseparable from the Newton adjunct of ordinary business or family dealing.

37 Challenge Corporation Ltd v Commissioner of Inland Revenue [1986] 2 NZLR 513 (CA) at 548 (emphasis added). See also GD Clews "The 'More Than Merely Incidental' Test in Tax Avoidance: What Does it Mean and How is it Applied" (2004) Geoffrey Clews: Barrister: Specialist Tax \& Trusts Counsel <www.taxcounsel.co.nz>, where the author refers to Richardson J as noting in that judgment, among other things: "(a) The Newton predication test (from Newton $v$ C of $T$ (1957) 96 CLR 577) allowed transactions to escape section 108 if they were capable to explanation by reference to ordinary business or family dealings."

38 Ben Nevis Forestry Ventures Ltd v Commissioner of Inland Revenue, above $\mathrm{n} 2$, at [81]. 


\section{THE DEMAND FOR GREATER LEGISLATIVE PRESCRIPTION}

The second - and related - trend after Elmiger was the growth of calls from the judiciary, practitioners and taxpayers for changes to s 108. The primary concern apparently was that the section was fundamentally incomplete, in that it did not state to whom the income earned under an offending arrangement was to be assessed. Another major concern, however, was that the section was too concise and general, and greater legislative guidance was required as to what arrangements were intended to be caught (or not), preferably with some specification of the identifying circumstances, types and/or criteria of such arrangements.

For example, the judgment of McCarthy P in Commissioner of Inland Revenue v Gerard opened with the following strongly worded passage: ${ }^{39}$

This appeal is from a judgment of Wilson $\mathrm{J}$ in the Supreme Court in which he raises his voice against the failure of the Legislature to take heed of the many criticisms of s 108 of the Land and Income Tax Act 1954, not only by Judges of this Court and the Supreme Court in New Zealand, but also by members of the Privy Council, Lord Donovan and Lord Wilberforce in particular, and against the Commissioner's extension of the operation of this extraordinarily difficult section into what he, Wilson J, called a world of fiscal phantasy. I think it proper that I should say that I think that strong words by the Judge were justified. ... As Wilson J points out, arguments on the application of s 108 are now rarely, if ever, based on the text of the section itself; they are mainly, if not wholly, centred on the glosses placed by the Courts on the text.

One can only hope that the Legislature will now listen to what has been said by the judiciary and by legal commentators, and will state in precise language not only what classes of transactions are to be struck down, but what are to be the results of that action.

Inland Revenue departmental files reveal that the President then wrote to the Attorney-General about the matter, saying: ${ }^{40}$

You may have seen in the newspapers some comments of mine in a judgment Commissioner of Inland Revenue v. Gerard. Their purpose was to draw the attention of the Legislature, once again, to the unsatisfactory state of s.108 of the Land and Income Tax Act. You will know of what the Privy Council and numerous legal commentators, as well as the New Zealand Judiciary, have said about this section.

I well understand that the responsibility for taxation legislation is strictly the province of the Minister of Finance, but the impact which this section is having on the work of the courts is a matter which would interest you. So I am sending you a copy of the judgments in this case.

39 Commissioner of Inland Revenue v Gerard, above n 23, at 280-281.

40 Letter from McCarthy P (President of the Court of Appeal) to the Honourable Martyn Finlay MP (AttorneyGeneral) regarding s 108 of the Land and Income Tax Act 1954 (23 May 1974), from departmental files, 
No doubt as a result of the misconceptions about the predication test discussed above, there was also particular interest at the time about the types of "ordinary business or family dealings" that it was believed were intended to be exempt. When amending legislation was mooted, submissions on those matters were made to the Government by, among others, the New Zealand Chamber of Commerce and the Federated Farmers of New Zealand, representing taxpayers typically involved in business and family dealings (the latter group being especially interested at the time in arrangements involving the transfer of farm land and/or assets into family trusts). ${ }^{41}$

\section{THE 1974 AMENDMENT}

The Land and Income Tax Amendment Act (No 2) 1974 was passed into law on 8 November 1974, with, among other things, s 108 being amended as follows: ${ }^{42}$

(2) Every arrangement made or entered into, whether before or after the commencement of this Act, shall be absolutely void as against the Commissioner for income tax purposes if and to the extent that, directly or indirectly, -

(a) Its purpose or effect is tax avoidance; or

(b) Where it has 2 or more purposes or effects, one of its purposes or effects (not being a merely incidental purpose or effect) is tax avoidance, whether or not any other or others of its purposes or effects relate to, or are referable to, ordinary business or family dealings,

whether or not any person affected by that arrangement is a party thereto.

It can be seen, first, that although the relevant part of that formulation was longer than its predecessor, it was not much longer (especially when one allows for subparagraphing); and much of the language of the old section was retained. The amendment was not materially more proscriptive than the rule that it replaced. The amended section thus retained the intrinsic requirement for a reasoning process that was determinative in nature (that is, predication) to enable taxpayers, their advisers and the courts to progress from facts to a legal result. ${ }^{43}$

The language of the amendment shows that the drafters sought expressly to incorporate, and at the same time to clarify and to strengthen, the essence of Lord Denning's second sentence. Lord Denning's "without necessarily" qualification was replaced, in subs 2(b), with the negative provision in parenthesis quoted above, "(not being a merely incidental purpose or effect)". This form of drafting is common in income tax legislation. Rather than aiming at specific targets, drafters write in

41 From departmental files, above n 32.

42 Land and Income Tax Amendment Act (No 2) 1974, s 9. For a useful discussion of the amendment at the time, see Ivor Richardson "And Now the New Section 108" [1974] NZLJ 560.

43 In other words, the amended section neither specified nor expressly removed the label and concept of predication, but neither did the old section: the process of predication was inherent in the application of the old, and remained inherent in the application of the new. 
all-embracing terms, from which they carve out exceptions. ${ }^{44}$ In drafting in this manner, the drafters in effect reversed the operation of the qualification, but they did not fundamentally alter it. Indeed, it is tolerably clear that by subs 2(b), the drafters not only confirmed both the correct meaning and the significance of the qualification, but they also confirmed that fundamentally the Newton predication test had been intended to be a two-step process.

The Inland Revenue Department's travaux in respect of the amendment show that: ${ }^{45}$ (i) the Commissioner strongly favoured both retention of the old wording and the Elmiger explanation of that wording as applying to it (hence, that he favoured the retention of the predication test); and (ii) the Commissioner saw the amendment quoted above as doing exactly that. The Commissioner summarised his position in a letter to the Minister of Finance only weeks before the amendment was passed into law: ${ }^{46}$

While there must always be a degree of uncertainty in this area Inland Revenue consider that the new version of section 108 does no more than give the proper balance between the Revenue and the taxpayer.

To sum up:

- Amendments were needed to the section to give effect to the criticism by the Courts that the old section was "unfinished", that is it did not state to whom the income involved was to be assessed when the arrangement etc. was voided for tax purposes.

- Opportunity was taken in the amendments to remove the adverse effects of dicta from New Zealand cases in the period subsequent to Elmiger.

- The amendments do no more than restate what Justice Woodhouse said in Elmiger in fact the language of the section and the quote (above) from his judgment, are very similar.

- The amendments give the same effect as the Australian decisions.

- The language of the old section is otherwise preserved as far as possible - so as to obtain the interpretations already given - rather than completely rewording the section. To do so would probably have meant a new series of cases.

In all circumstances no further amendments seem necessary.

The travaux reveal no evidence or even suggestion that any of the major interest groups who lodged submissions thought that the amendment was intended to "dispense with" the Newton predication test, or even that that test was considered to be "old" or in need of renovation. Certainly

44 Section BD 1(1) of the Income Tax Act 2007 is a dramatic example. It taxes all income of every natural or juristic person in the world (or arguably in the universe), leaving it to s BD 1(3)(b) to exclude foreign source income of foreign residents.

45 From departmental files, see above n 32.

46 See Part VII and n 32, above. 
the amendment made it clear, by subs (2)(b), that the fact that an arrangement might be an ordinary business or family dealing would not of itself save it from also constituting tax avoidance. But as we have seen, that proviso simply confirmed and strengthened the Newton qualification about such dealings and removed the misconception of protection that had arisen about them.

In conclusion, then, it can be seen that, contrary to the later judicial dicta, the 1974 amendment did not dispense with the predication test, either in intention or in fact. If the amendment dispensed with anything, it dispensed with the misconception that ordinary business and family dealings as such could be determinative of avoidance questions (that is, the mischaracterisation of the Newton and Elmiger predication test). Further, the amendment gave the quietus to the principal purpose test that had thrived since Mangin, and adopted instead the Hollyock formulation of "merely incidental purpose or effect". 47

\section{PREDICATION IN THE CURRENT NEW ZEALAND GAAR}

In 1976, the amended s 108 became s 99 of the Income Tax Act 1976. Section 99 was then carried through substantively in that same form to ss BG 1 and GB 1 of the Income Tax Act 1994 (being the provisions in issue in Ben Nevis), and then to ss BG 1 and YA 1 of the current Income Tax Act 2007. The GAAR retains the same words in the Income Tax Act 2007, but in the disaggregating drafting style of that Act, is scattered to different parts of the statute. The main provisions are:

Section BG 1 Tax avoidance

Avoidance arrangement void

(1) A tax avoidance arrangement is void as against the Commissioner for income tax purposes.

Reconstruction

(2) Under Part G (Avoidance and non-market transactions), the Commissioner may counteract a tax advantage that a person has obtained from or under a tax avoidance arrangement.

[Sections CD 11 and CW 63 (avoidance arrangements) tax sums that sections GA 1 and GB 1 assign income to persons who would otherwise benefit from tax avoidance arrangements.]

Section YA 1 Interpretation

arrangement means an agreement, contract, plan, or understanding, whether enforceable or unenforceable, including all steps and transactions by which it is carried into effect

tax avoidance includes-

47 See Hollyock v Federal Commissioner of Taxation, above n 34, at 657. 
(a) directly or indirectly altering the incidence of any income tax:

(b) directly or indirectly relieving a person from liability to pay income tax or from a potential or prospective liability to future income tax:

(c) directly or indirectly avoiding, postponing, or reducing any liability to income tax or any potential or prospective liability to future income tax

tax avoidance arrangement means an arrangement, whether entered into by the person affected by the arrangement or by another person, that directly or indirectly-

(a) has tax avoidance as its purpose or effect; or

(b) has tax avoidance as 1 of its purposes or effects, whether or not any other purpose or effect is referable to ordinary business or family dealings, if the tax avoidance purpose or effect is not merely incidental

Because the amended s 108 was so clearly based on Woodhouse J's words in Elmiger, and because the formulation has not materially changed since 1974, the current New Zealand GAAR remains closely based on the same dicta. Moreover, because Elmiger itself expressly adopted the predication test, it is indisputable that the current GAAR still encapsulates that test, and/or that that test remains highly pertinent to its application. Certainly there is no reason or authority anywhere to say that the in-principle process of predication as envisaged by Lord Denning must not, cannot or need not be part of the courts' application of the current GAAR to individual cases.

\section{THE DECISION IN BEN NEVIS}

We now turn to Ben Nevis itself. ${ }^{48}$ We have seen that the majority judgment's traversal of the history of the 1994 GAAR, which applied in that case, appeared to repeat a common error about the status of the predication test. ${ }^{49}$ Nevertheless, the Court found itself still grappling with the same interpretation challenge that Lord Denning had answered; so it embarked on solving the problem again.

The case concerned a complex 50-year forestry investment tax shelter under which investors (the taxpayers) sought to claim from the outset significant annual tax deductions for amortised licence fees and insurance premiums that in theory were not actually payable until near the maturation of the scheme, many years later, and that in practice were unlikely to be payable even then. The taxpayers argued that all the steps in the transaction, and the deductions claimed, complied with various specific provisions in the Income Tax Act 1994, which therefore meant that the scheme was within the legislature's contemplation as being allowable, and was thus not in breach of the GAAR. In essence, therefore, the issue for the Court was how the GAAR was to be construed at the same time as giving proper effect (which might mean no effect) to the specific deductions

48 Ben Nevis Forestry Ventures Ltd v Commissioner of Inland Revenue, above n 2.

49 See Parts I and VII above. 
provisions on which the taxpayers relied as the foundation for a scheme that the Commissioner impugned as a tax avoidance arrangement. In the words of the majority judgment:

[83] The amendments to s 108 in 1974 did not, however, explicitly address how to discern the relationship between allowing tax concessions for certain arrangements and the general anti-avoidance provision, which struck down arrangements having a purpose of tax avoidance that was not merely incidental. ... The result is that this difficulty remains, and is the central issue in this case.

[100] ... There is therefore continuing uncertainty about the interrelationship of the general antiavoidance provision with specific provisions. That makes it desirable for this Court to settle the approach which should be applied in New Zealand.

Before examining the relationship between the GAAR and specific provisions of the Act, the majority ${ }^{50}$ noted the deliberately non-specific nature of the GAAR, thus, it is submitted, highlighting the challenge that this article is concerned with, namely the challenge of determining just what process courts should observe in applying the GAAR: ${ }^{51}$

... we keep in mind that the present form of the general anti-avoidance provision remains largely the same as that adopted in 1974, when Parliament chose, in reframing the then s 108, not to specify with any particularity the kind of arrangements to which it would apply. This was left to the courts to work out. Parliament did not regard it as inconsistent with the judicial function for the courts to decide which arrangements, having a purpose or effect of saving tax, would be caught by the amended general antiavoidance provision. Of greater legislative concern was that however carefully the general provision might be drafted, the results of taxpayers' ingenuity in adapting the forms in which they did business could not be predicted.

The judgment continued: ${ }^{52}$

It is accordingly the task of the courts to apply a principled approach which gives proper overall effect to statutory language that expresses different legislative policies. It has long been recognised those policies require reconciliation. The approach must ensure that the particular case before the court is examined by reference to the respective legislative policies. It must enable decisions to be made on individual cases through the application of a process of statutory construction focusing objectively on features of the arrangements involved, without being distracted by intuitive subjective impressions of the morality of what taxation advisers have set up.

50 The minority judgment of Elias CJ and Anderson J (at [1]-[10]) disagreed that a process of reconciliation between the general and specific provisions was required, preferring the approach that a proper purposive and contextual interpretation of each relevant provision would yield the overall intended legislative result. The minority also offered brief views on the correct interpretation and ambit of the GAAR. Neither matter directly bears on the present topic.

51 At [101].

52 At [102] (emphasis added) (footnote omitted). 
The approach that the Court described there is none other than an exercise in logic of inprinciple predicative reasoning (that is, predication), whereby the proposition (that is, tax avoidance) can be established or not directly from an examination of the features of its subject (that is, the facts of the arrangement). Of course, the Court in the passage quoted was primarily referring to the correct approach to reconciling the GAAR with specific provisions of the Act (in the Ben Nevis case, to provisions that allowed certain deductions) and not specifically to the correct approach to determining whether an arrangement breached the GAAR. However, in our submission, not only is there for present purposes ultimately no real difference between the two enquiries, but also, in any event, the analytical or determinative process being followed is exactly the same, and this process is the process of predication.

The Court then proceeded to explain the correct approach to the reconciliation process, and, without using the term, to include predication as part of that process:

[107] ... If that is shown, a further question arises based on the taxpayer's use of the specific provision viewed in the light of the arrangement as a whole. If, when viewed in that light, it is apparent that the taxpayer has used the specific provision, and thereby altered the incidence of income tax, in a way which cannot have been within the contemplation and purpose of Parliament when it enacted the provision, the arrangement will be a tax avoidance arrangement. For example, the licence premium was payable for a "right to use land", according to the ordinary meaning of those words, which of course includes their purpose. But because of additional features, to which we will come, associated primarily with the method and timing of payment, it represented and was part of a tax avoidance arrangement.

[108] The general anti-avoidance provision does not confine the court as to the matters which may be taken into account when considering whether a tax avoidance arrangement exists. Hence the Commissioner and the courts may address a number of relevant factors, the significance of which will depend on the particular facts. The manner in which the arrangement is carried out will often be an important consideration. So will the role of all relevant parties and any relationship they may have with the taxpayer. The economic and commercial effect of documents and transactions may also be significant. Other features that may be relevant include the duration of the arrangement and the nature and extent of the financial consequences that it will have for the taxpayer. As indicated, it will often be the combination of various elements in the arrangement which is significant. A classic indicator of a use that is outside parliamentary contemplation is the structuring of an arrangement so that the taxpayer gains the benefit of the specific provision in an artificial or contrived way. It is not within Parliament's purpose for specific provisions to be used in that manner.

With one apparent difference, the GAAR predication process described by the Court at [108] is exactly the reasoning of the Newton predication test: the Court's phrase - "the manner in which it is carried out" - is coterminous with the subject of Lord Denning's predication, that is, "the overt acts by which [the arrangement] was implemented". 53

53 Newton $v$ Commissioner of Taxation of the Commonwealth of Australia, above n 12, at 465-466 (emphasis added). 
The apparent difference was that the majority judgment added a list of matters that could be taken into consideration in the predication exercise, namely: (i) the role of other parties and their relationship with the taxpayer; (ii) the economic and commercial effect of documents and transactions; (iii) the duration of the arrangement; (iv) the nature and extent of its financial consequences for the taxpayer; and (v) the particular combination of various elements of the arrangement. Those additions, however, make the apparent difference between the Ben Nevis test and the Newton predication test a distinction without a true difference. They do no more than develop and enhance the test and give examples of factors to consider in putting the test to work, and they neither replace the test nor change its essence: the end result in Ben Nevis should, and probably would, have been the same under either formulation of the test. The real point is, in both Newton and Ben Nevis, the actual analytical process identified and described for general use in respect of the GAAR was essentially the same.

\section{CONCLUSION: REHABILITATION OF PREDICATION}

The Ben Nevis case is a comprehensive and useful restatement of the test for tax avoidance in New Zealand, and provides helpful insights into the history and purpose of the GAAR. But it is clear from both the terms of the Land and Income Tax Amendment Act (No 2) 1974 and the Inland Revenue Department's records that the Court in Ben Nevis erred in thinking that the 1974 amendment dispensed with the predication test or that the policy makers or Parliament had any intention of doing so. Moreover, analysis shows that, in applying the equivalent of the current GAAR, the Court used the same logical process of that test anyway. The net result is that the essence of a previously misunderstood and discarded universalisable GAAR test from 50 years ago, namely logical reasoning by predication, has in fact continued to be used by the New Zealand courts frequently since then, and was reinstated in the Ben Nevis case as the canonical test without recognition of its true nature or provenance.

The authors submit that the label "predication test" should be restored to use. The amplified form of the test set out in Ben Nevis, with examples of factors to be taken into consideration, which was described in the Part IX of this article, has considerable merit. Giving examples of the kinds of transactions and factors that might indicate a purpose of tax avoidance, as the Supreme Court did in Ben Nevis, makes the test more understandable than Lord Denning's simple reference to "overt acts"54 that may lead one to predicate an avoidance purpose. Nevertheless, the essence of the amplified test in Ben Nevis is exactly the same as the original in the Newton case, and, because no other reasoning process can be used now that the Supreme Court has spoken, (nor, while GAARs remain deliberately general in their expression and contain no additional rules, could there be another reasoning process), there is no good reason why the label "predication" could or should not be restored to use.

54 At $465-466$. 
We reiterate that the mere use of the word "predication" itself will never provide the answer to the question in any particular case: only the exercise of predication can do that. However, predication's rehabilitation as the correct description of the process that the courts use is consistent with jurisprudential integrity. Further, rehabilitation should serve to reduce the challenge of how to apply the GAAR that is faced by every court in every avoidance case, and the risk of confusion and inconsistency arising between decisions. The term, "predication", may also assist practitioners and taxpayers contemplating novel or complex arrangements to know that those arrangements could well be viewed later through that very lens, because the lens of predication is by its nature one that taxpayers can themselves use in advance. Finally, everyone involved with tax law needs some shorthand expression to describe the test for tax avoidance. "Predication" is an excellent candidate. It is a complicated word, not used in many other contexts. It is unlikely, therefore, to cause confusion, its meaning is precisely correct, and it has history in this context going back nearly 70 years. 